\title{
Suomalaisen maatiaiskanan säilytysohjelma
}

Tiina Tuovinen

MTT Biotekniikka- ja elintarviketutkimus, 31600 Jokioinen, tiina.tuovinen@mtt.fi

\section{Tiivistelmä}

Suomessa on yli 170 innokasta maatiaiskanan pitäjää. Heillä oli vuonna 200813 eri maatiaiskantaa, yhteensä noin 2200 kanaa ja lähemmäs 600 kukkoa. Maatiaiskanan säilytysohjelmaa koordinoi MTT Biotekniikka- ja elintarviketutkimus. Ohjelma käynnistyi yli kymmenen vuotta sitten vuonna 1998. Perustamisvuodesta on ohjelmassa mukanaolevien sekä kasvattajien että eläinten määrä kolminkertaistunut. Suomi on kansainvälisin sopimuksin sitoutunut kotieläingeenivarojen säilyttämiseen. Työtä varten on laadittu Suomeenkin kansallinen eläingeenivaraohjelma. MTT koordinoi ohjelmaa ja on mukana geenivarojen säilytyksen ja kestävän hyödyntämisen tutkimus- ja kehittämistyössä. Maatiaiskanan säilytys on tiloilla tapahtuvaa in-situ-säilyttämistä, kanat kasvatetaan lajityypillisen käyttäytymisen mahdollistavissa lattiakanaloissa. Säilytysohjelmassa keskitytään toistaiseksi kanakantojen vahvistamiseen ja rodun geneettisen monimuotoisuuden turvaamiseen ja lisäämiseen.

Maatiaiskanakannoilla tarkoitetaan maassamme ennen 1900-luvulla alkanutta teollista kanatuotantoa eläneitä, paikallisiin olosuhteisiin sopeutuneita kanakantoja. Säilytysohjelman kanaaines on peräisin tiloilta, joilla tätä vanhaa kana-ainesta oli jäljellä.

Säilytysohjelman tiedonkeruu perustuu kasvattajien ohjelmaan ilmoittautuessa antamiin perustietoihin ja kerran vuodessa lähettämiin raportteihin. Tiedot tallennetaan maatiaiskanarekisteriin, josta saadut eläinmäärät ovat pohjana rodun tilaa kuvaaville tilastoille.

Lukumäärien lisäksi vuosiraporteissa kysytään eläinten hedelmällisyysominaisuuksia ja höyhenpuvun värejä. Maatiaiskanat munivat keskimäärin 0,5-0,6 munaa päivässä ja saavuttavat sukukypsyyden 22-24,5 viikon ikäisinä. Tyypillinen maatiaiskanan höyhenpuvun väri on musta, ruskea, punainen tai vaalea, kukon musta, ruskea, kirjava tai punainen. Munat ovat pieniä tai keskikokoisia, väriltään kermanvärisiä, beigejä tai ruskeita. Maatiaiskanasta hyödynnetään munien lisäksi myös lihaa ja höyheniä, teuraskukkojen kasvatus on yleistä.

Maatiaiskana on rotuna edelleen vaarantunut, kaikki kannat uhanalaisia ja jotkut jopa kriittisesti uhanalaisia Ainakin yksi kanta ehti kuolla sukupuuttoon säilytysohjelmasta huolimatta.

\section{Asiasanat}

Maatiaiskana, säilytysohjelma, eläingeenivarat, geneettinen monimuotoisuus 


\section{Johdanto}

Suomi on monin kansainvälisin sopimuksin sitoutunut geenivarojen säilyttämiseen. MTT on mukana Suomen niin kasvi- kuin eläingeenivarojenkin säilytyksen ja kestävän hyödyntämisen tutkimus- ja kehittämistyössä. Työtä varten on laadittu maa- ja metsätalousministeriön, tutkimuksen, jalostus- ja muiden alan järjestöjen kanssa kansallinen eläingeenivaraohjelma. Ohjelmaa alettiin toteuttaa vuonna 2004. Maatiaiskanan osalta ohjelman toimeenpanosta huolehtii MTT Biotekniikka- ja elintarviketutkimus ja sen säilytysohjelma käynnistyi vuonna 1998. Maatiaiskanan säilytys on tiloilla tapahtuvaa in-situ-säilyttämistä. Maatiaiskanalat ovat lattiakanaloita, joissa on useimmiten ikkunat, aina orret, pesät sekä kuopsutus- ja kylpymahdollisuus. Kanat pääsevät laiduntamaan kesäisin.

Suomen kansallisen eläingeenivaraohjelman toimenpiteiden tavoitteena on, että 1) uhanalaiset alkuperäisrodut eivät kuole sukupuuttoon, 2) alkuperäisrotuja ylläpidetään taloudellisesti kestävällä tavalla, 3) geneettinen vaihtelu säilyy kotieläinroduissa mahdollisimman laajana, 4) kotieläinten tuotantokyvyn ja kestävyyden tasapainoinen kehittäminen on huomioitu jalostusohjelmissa ja 5) kotieläingenetiikkaan, jalostukseen ja kotieläingeenivaroihin liittyvää osaamista ja tietoutta ylläpidetään ja vahvistetaan. Tavoitteet 1-3 on maatiaiskanan osalta saavutettu, ja säilytysohjelmassa keskitytään toistaiseksi kanakantojen vahvistamiseen ja rodun geneettisen monimuotoisuuden turvaamiseen ja lisäämiseen.

Maatiaiskanakannoilla tarkoitetaan maassamme ennen 1900-luvulla alkanutta teollista kanatuotantoa eläneitä, paikallisiin olosuhteisiin sopeutuneita kanakantoja. Säilytysohjelman kanaaines on peräisin kantatiloilta, joilla tätä vanhaa kana-ainesta oli jäljellä. Kantatiloilta saivat eläimensä ohjelman säilyttäjät ja poikastuottajat. Ohjelmaan osallistuvista muodostuu vähitellen koko Suomen kattava verkosto. Maatiaiskanoja kasvatetaan myös säilytysohjelmaan kuulumattomilla tiloilla, mutta näiden eläinten määrästä tai rotupuhtaudesta ei ole tietoja.

\section{Aineisto ja menetelmät}

Säilytysohjelman tiedonkeruu perustuu ohjelmaan hyväksyttäessä annettaviin perustietoihin ja niiden päivityksiin sekä kasvattajien kerran vuodessa lähettämiin raportteihin. Perustietokyselyssä selvitetään lisäksi kanankasvattajan toimintaympäristöä ja tuotannon markkinointia.

Vuosiraporteissa kysellään kanojen ja kukkojen, syntyneiden untuvikkojen sekä tuotantoon jätettyjen kananuorikoiden ja nuorten kukkojen määriä, sukukypsyysikää ja munatuotosta/kana/pv. Lisäksi kysellään munien kokoa ja väriä sekä kukkojen ja kanojen höyhenpeitteen väriä. Hedelmällisyysominaisuuksia koskevia tietoja on kerätty vuodesta 2001 alkaen, höyhenpukujen väritystä sekä munien kokoa ja väriä koskevia tietoja vuodesta 2003 lähtien. Vuonna 2009 lähetettiin säilytysohjelmaan kuuluville kysely maatiaiskanojen höyhenien käytöstä ja kannustettiin säilyttäjiä tarkkailemaan kanojensa hyvinvointia LayWel - käytännön mukaisilla kana-, parvi- ja kanalakohtaisilla lomakkeilla.

\section{Tulokset ja tulosten tarkastelu}

Säilytysohjelmassa mukanaolevista kanankasvattajista 132 palautti vuosiraportin vuonna 2008. Näistä poikastuottajia oli 12. Tiloilla oli 2163 kanaa ja 572 kukkoa. Kanankasvattajissa oli ammattimaisia siipikarjan kasvattajia, mutta suuri osa oli harraste- ja omatarvetuotantomuotoisen pienkanalan pitäjiä. Vuosina 1998-99 aloittaneista on mukana vielä 29 pitkän linjan kanankasvattajaa. Yli puolella kasvattajista on myös muita maatiaisrotuja kotieläiminä. Eniten on maatiaislampaita, mutta myös suomenkarjaa sekä suomenvuohia on jonkin verran. Muutama pitää suomenhevosia ja paimensukuisia ajokoiria. 50 tilalla on munanmyyntiä ja myös 28 säilyttäjää on myynyt poikasia. Luomutuotannossa on 22 tilaa. Tiloilla maatiaiskanoilla on mahdollisuus lajityypilliseen käyttäytymiseen ja ulkoiluun joko tarhassa tai vapaasti pihalla. Lintuinfluenssauhan torjumiseksi annettu sisälläpitomääräys rajoittaa ulkoilua keväällä. Joissakin tapauksissa siihen on voinut hakea kunnaneläinlääkäriltä osittaista vapautusta.

Suuri osa säilyttäjistä lisäsi kanojaan kanan alla haudottaen; poikastuottajista vain 3 luotti tähän lisäystapaan. Kuvassa 1 nähdään säilytysohjelman eläinten ja tilojen määrän kehitys. 


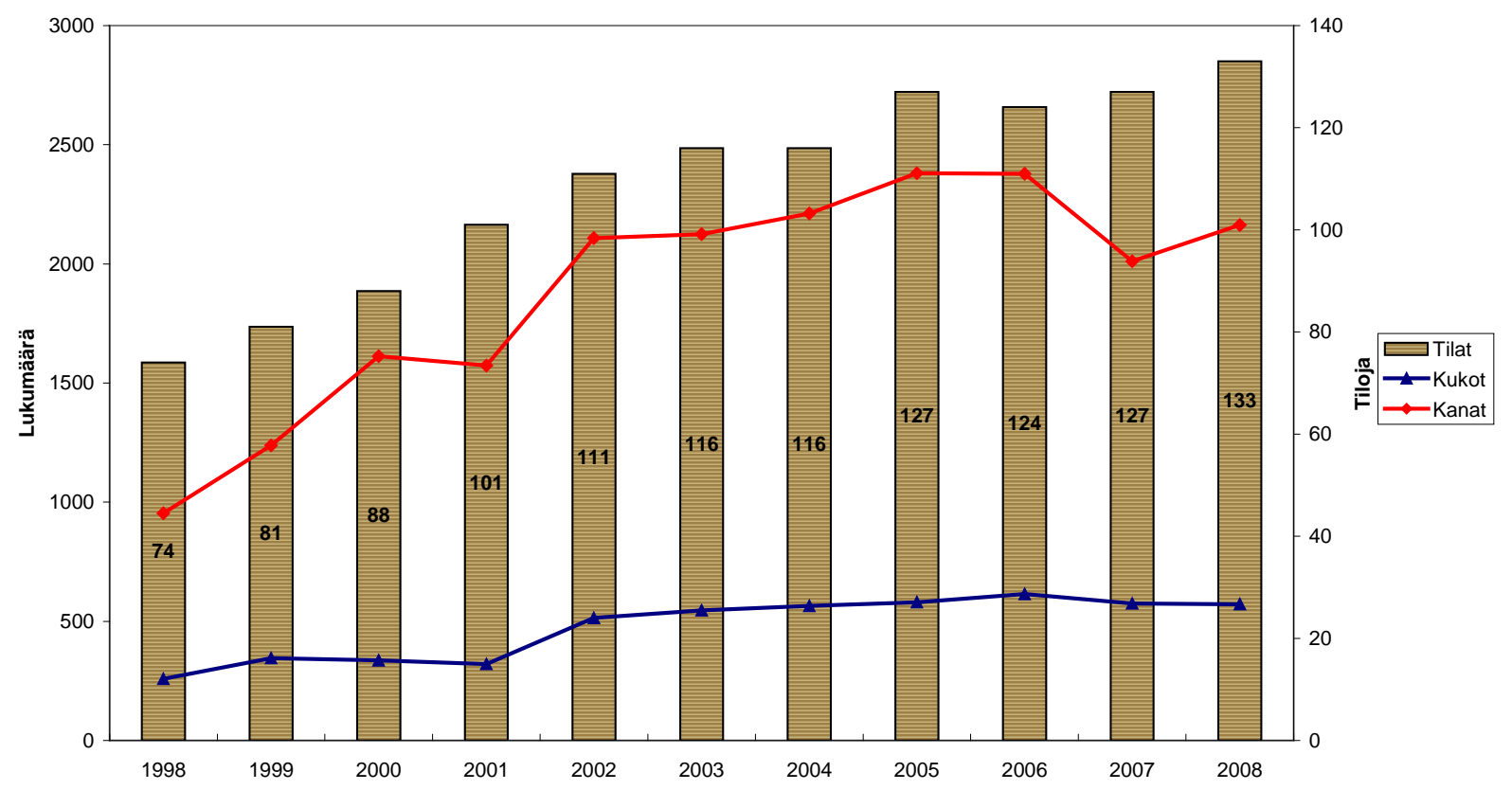

Kuva 1. Kanojen ja kukkojen sekä tilojen määrän kehitys vuosina 1998-2008.

Säilytyssopimuksia tehdään vähintään neljäksi vuodeksi. Eläinten määrä nousi vuoteen 2006 saakka, jolloin tärkeä poikastuottaja joutui luopumaan eläintenpidosta. Tilanne korjaantunee vähitellen; vuosi 2009 on ollut voimakkaan kasvun aikaa. Parvet ovat pieniä, vuonna 2008 tiloilla oli keskimäärin 16 kanaa ja 4 kukkoa. Säilyttäjäverkosto on laajentunut vuosien saatossa. Verkko on tihein Etelä- ja Keski-Suomessa ja harvenee pohjoista kohti siirryttäessä (kuva 2).

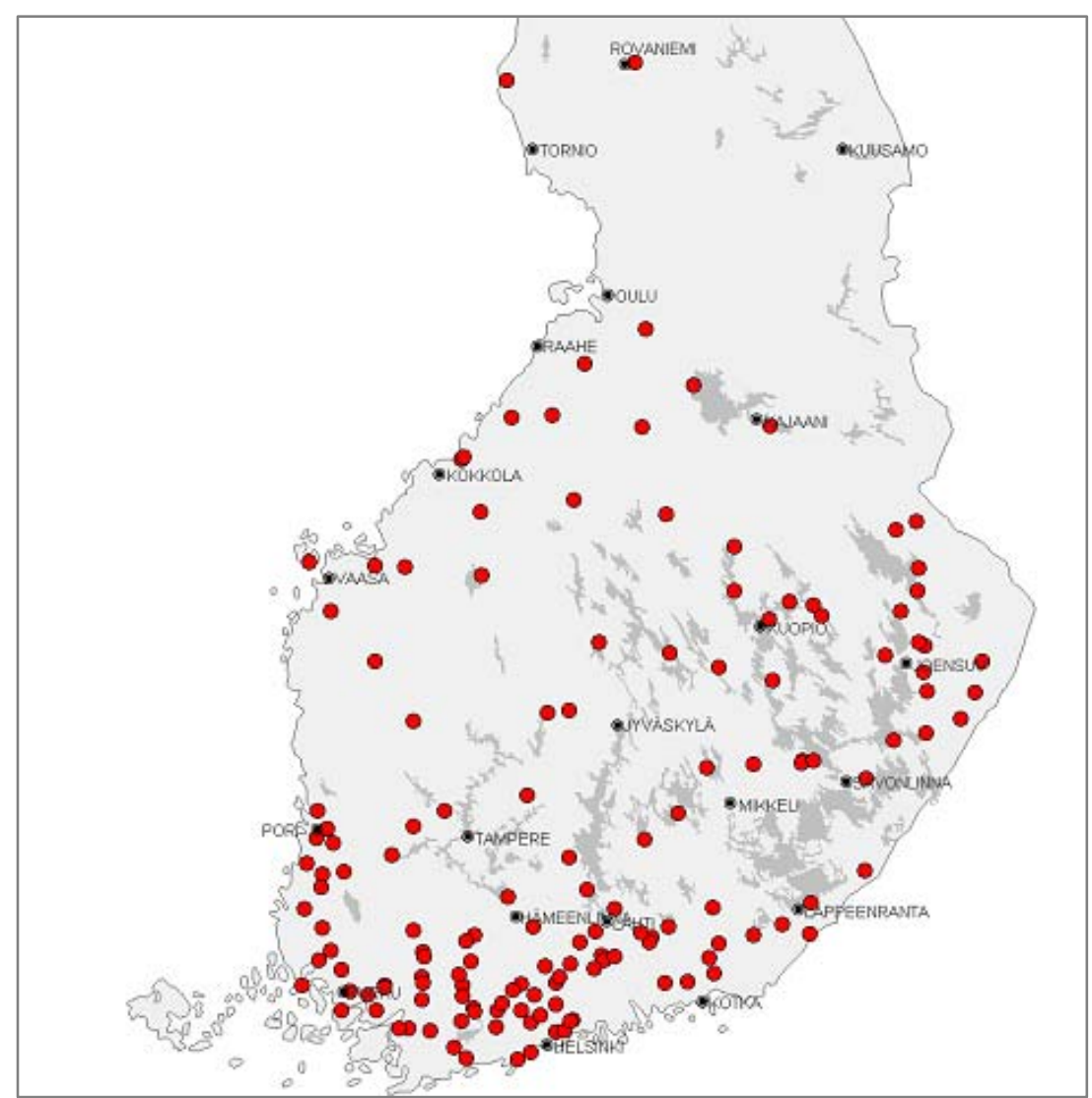

Kuva 2. Maatiaiskanan säilyttäjätilat vuonna 2008. 
Kanakantojen avulla ylläpidetään rodun sisällä monimuotoisuutta. Kanakannat ovat saaneet nimensä löytöpaikkansa tai pitkäaikaisen säilyttäjänsä mukaan. Viimeksi pelastettiin sukupuutolta Eurajoen Hornion kylästä horniolainen kanta. Säilytysohjelman myötä kanakannat ovat levinneet laajalti alkuperäisen kotipaikkakuntansa ulkopuolelle. Säilytettävien kanakantojen osuudet muuttuvat eläinmäärän kasvaessa. Savitaipaleen kanan ja piikkiöläisen kannan osuus on laskenut ja Alhon sekä horniolaisen osuus kasvanut. Osuuksien järjestys vaihtelee vuosittain saatavana olevien poikasten kannan ja säilyttäjien mieltymysten mukaan (kuva 3).

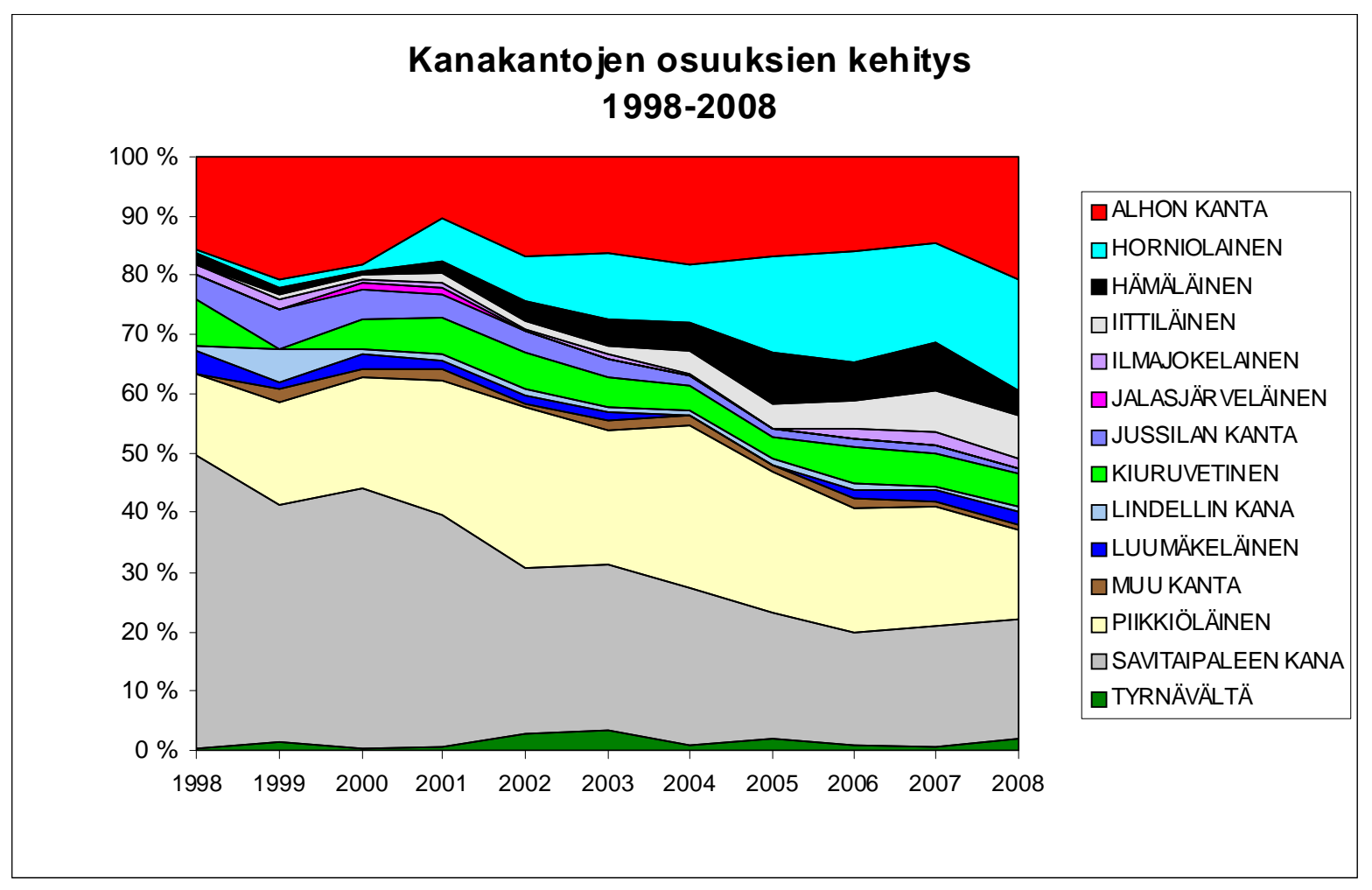

Kuva 3. Kanakantojen osuuksien kehitys 1998-2008

Suomalainen maatiaiskana on edelleen kanarotuna vaarantunut, ja kaikki sen yksittäiset kannat joko uhanalaisia tai kriittisesti uhanalaisia. Taulukko 1. Kanakannoista suuri osa on edelleen niin pieniä, että vaikka ne vuosien työn tuloksena ovat nousseet kriittisesti uhanalaisten luokasta uhanalaisiin, ne voivat helposti pudota takaisin kriittisesti uhanalaisten luokkaan esimerkiksi kananpidosta luopumisen tai haudontojen epäonnistumisen vuoksi. Kriittisesti uhanalaisia kanakantoja uhkaa myös sukusiitos.

Horniolainen kanta pelastui viime hetkellä sukupuutolta, ja tämä kanta on tehokkaiden suojelutoimenpiteiden ansiosta yleistynyt niin, ettei se enää ole kriittisesti uhanalainen.

Taulukko 1. Maatiaiskanakantojen tila.

\begin{tabular}{|c|l|l|}
\hline Lisääntyviä naaraita & Populaation tila & Kanakanta \\
\hline$>=10.000$ & Normaali & \\
\hline $5.000-9.999$ & Harvinainen & \\
\hline $1.000-4.999$ & Vaarantunut & Suomalainen maatiaiskana \\
\hline $100-999$ & Uhanalainen & $\begin{array}{l}\text { Alhon, horniolainen, iittiläinen, kiuruvetinen, } \\
\text { piikkiöläinen, Savitaipaleen kana }\end{array}$ \\
\hline $1-99$ & Kriittisesti uhanalainen & Muut maatiaiskanakannat \\
\hline 0 & Kuollut sukupuuttoon & Jalasjärveläinen \\
\hline
\end{tabular}


Maatiaiskanalla ei ole jalostusohjelmaa, joten siitoseläimiä ei valita hedelmällisyys- (sukukypsyysikä, munatuotos tms) tai ulkoisten ominaisuuksien (koko, väri) perusteella. Sairaat, epämuodostuneet ja rotuominaisuuksiensa puolesta poikkeavat (esim. höyhenjalkaiset) yksilöt saa karsia parvesta pois.

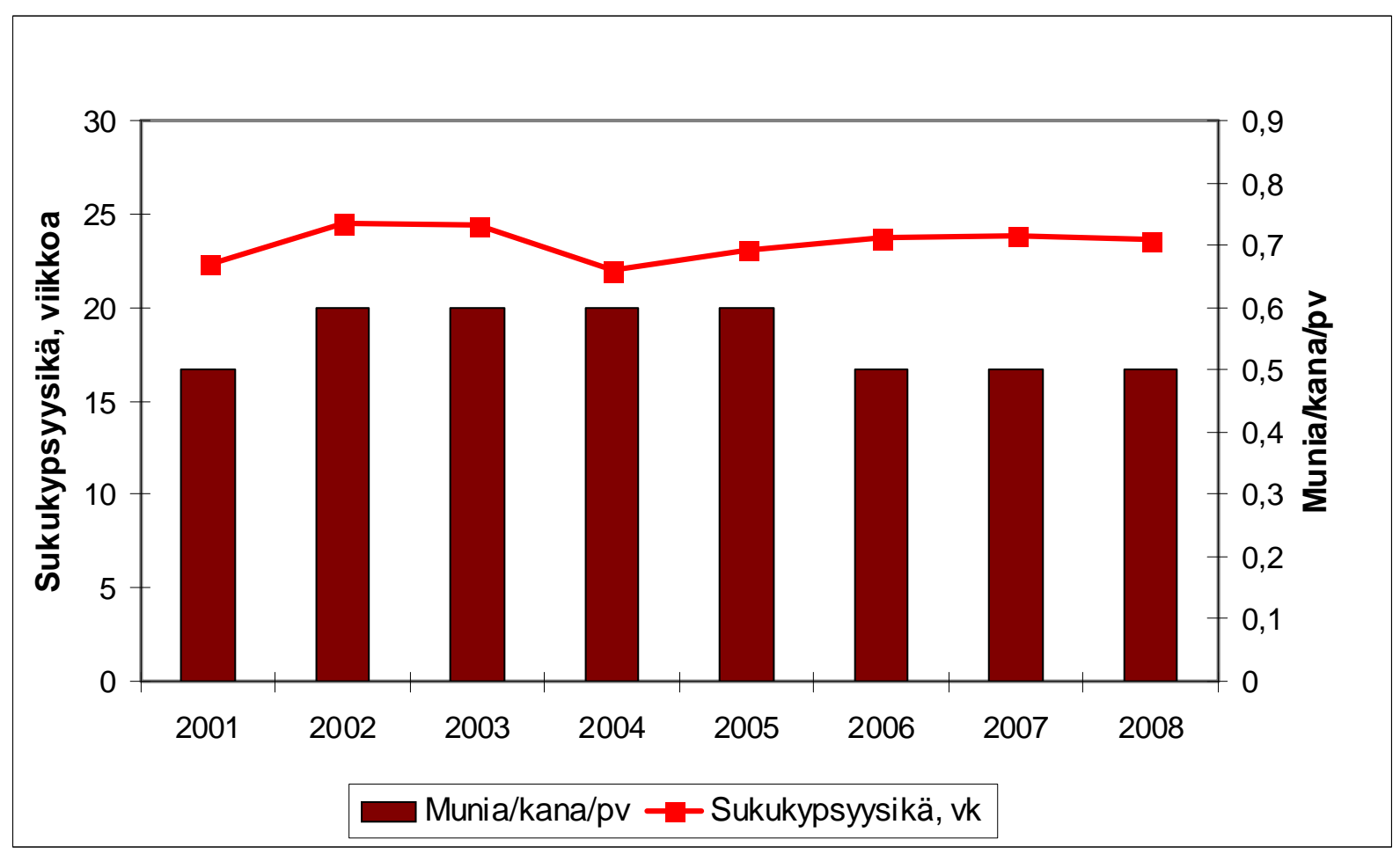

Kuva 4 Munatuotos/kana/pv ja sukukypsyysikä 2001-2008.

Maatiaiskana saavuttaa sukukypsyyden keskimäärin 22-24,5 viikon ikäisenä ja munii keskimäärin 0,50,6 munaa päivässä (kuva 4). Hedelmällisyysominaisuuksissa maatiaiskana ei pysy kilpailemaan kaupallisten munijarotujen kanssa.
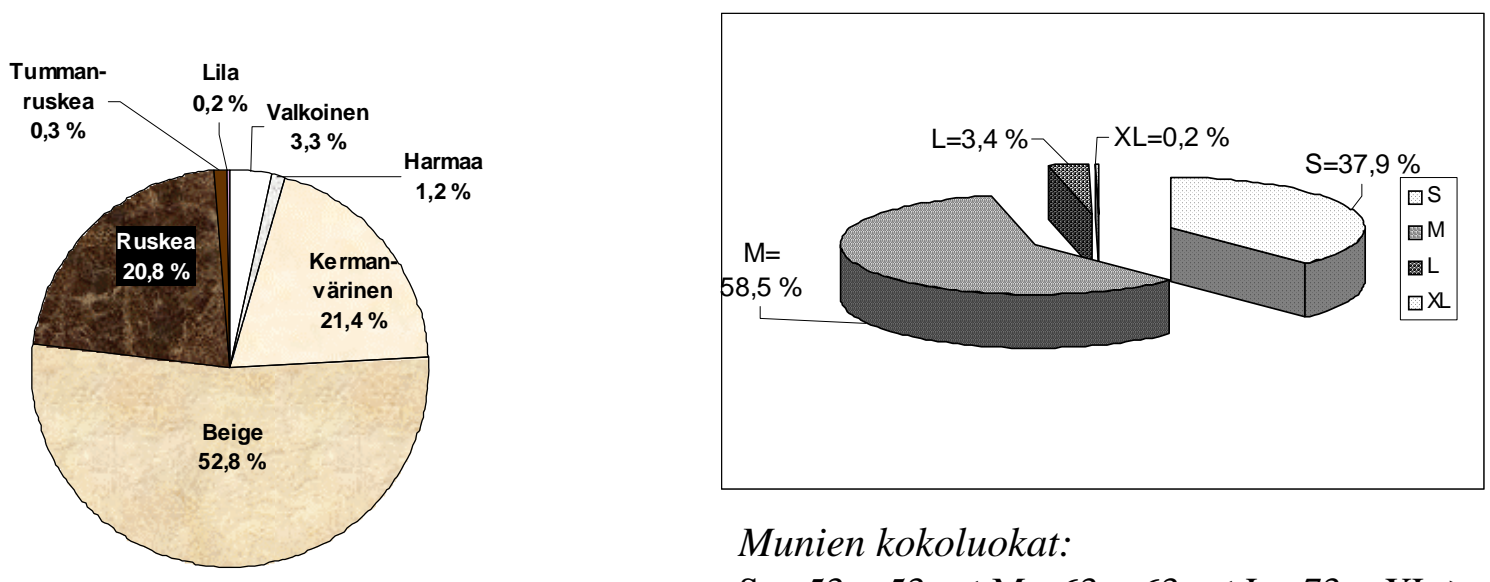

Munien kokoluokat:

S < 53g; 53g $\leq \mathrm{M}<63 \mathrm{~g} ;$ 63g $\leq \mathrm{L}<73 \mathrm{~g} ; \mathrm{XL} \geq$ $73 g$.

Kuvat 5 ja 6. Munien väriosuudet ja kokoluokat.

Munat ovat väriltään enimmäkseen kermanvärisiä, beigejä tai ruskeita ja kooltaan pieniä tai keskikokoisia (kuvat 5 ja 6). Maatiaiskanat ovat pääväriltään mustia tai ruskeita, vähemmän on punaisia tai vaaleita yksilöitä. Yli puolet kukoista on pääväriltään mustia, lopuista on valtaosa joko 
ruskeita, kirjavia tai punaisia. Kuvassa 7 on tyypillisten ruskean ja mustan kanan ja kirjavan kukon lisäksi myös harvinaisempaa värityyppiä edustava harmaa kana Eri kantojen välillä on eroja höyhenpukujen värien osuuksissa; hämäläisen kannan yksilöistä yli puolet on mustia. Eri kanakannoilla ei kuitenkaan ole kullekin kannalle ominaista värityyppiä. Käytännössä mitä suuremmaksi jonkin kannan yksilömäärä kasvaa, sitä runsaammaksi käy höyhenpukujen värien kirjo.

Maatiaiskanan höyhenet voidaan värikylläisinä hyödyntää monin tavoin esim. askartelussa, koristelussa ja perhonsidonnassa. Teuraskukkojen niskahöyhenet ovat erinomaista sidontamateriaalia. (kuva 8).
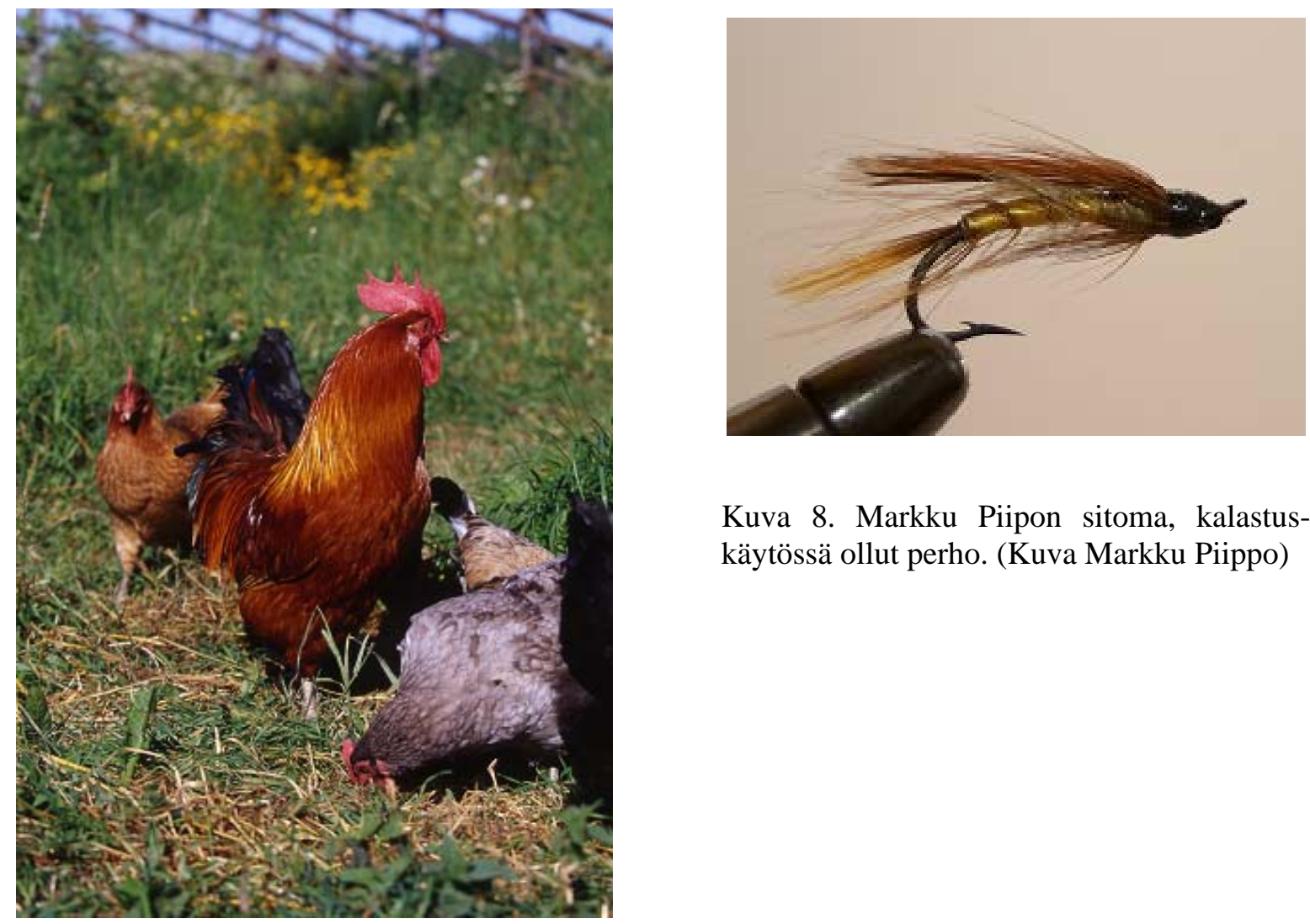

Kuva 8. Markku Piipon sitoma, kalastuskäytössä ollut perho. (Kuva Markku Piippo)

Kuva 7. Maatiaiskukko ja kanoja. (Kuva Tapio Tuomela)

Maatiaiskanojen kasvattajilla on vuodesta 2010 lähtien mahdollisuus tarkkailla eläintensä hyvinvointia LayWel-käytännön avulla. Ammattimaiset siipikarjankasvattajat ovat omavalvonnan piirissä.

Säilyttäjiin pidetään yhteyttä tiedottein ja henkilökohtaisten kontaktien avulla. Internet ja sen keskustelupalstat ovat osoittautuneet tärkeäksi tiedonhankintaväyläksi uusia säilyttäjiä rekrytoitaessa. Vuosittain pidettävä maatiaiskanaseminaari kokoaa yhteen käytännön säilytystyötä tekeviä, tutkijoita ja muita geenivarojen säilyttämisen ja kestävän käytön asiantuntijoita.

\section{Johtopäätökset}

Maatiaiskanan säilytysohjelmassa on nyt saavutettu kotieläinten geenivaraohjelman 3 ensimmäistä tavoitetta: 1) maatiaiskana on pelastettu sukupuutolta, 2) sitä ylläpidetään taloudellisesti kestävällä tavalla omatarvetuotannossa pienkanaloissa ja 3) rodun geneettistä monimuotoisuutta ylläpidetään eri kantojen avulla. Osittain on toteutunut myös tavoite 5) kotieläingenetiikkaan, jalostukseen ja kotieläingeenivaroihin liittyvää osaamista ja tietoutta ylläpidetään ja vahvistetaan

Jatkossa pyritään rekrytoimaan lisää säilyttäjiä ja saamaan maatiaiskana säilymään omana kanarotunaan, selvittämään eri kantojen geneettisiä eroja DNA-tutkimuksin ja nostamaan kaikkien kantojen status kriittisesti uhanalaisesta ylöspäin. Kun kanapopulaation koko on riittävän suuri ja perinnöllisesti monimuotoinen, sen tuotantokyvyn ja kestävyyden tasapainoinen kehittäminen on mahdollista. 


\section{Kirjallisuus}

Kantanen, J., Tuovinen T. 2008. Ohjelmoitu maatiaiskanan säilytys alkoi kymmenen vuotta sitten. Eläingeenivarat 1/2008: 10-11.

Kantanen, J. 2008. Suomen kansallinen eläingeenivaraohjelma. Eläingeenivarat 1/2008: 4-5.

Kantanen, J. 2005. Suomalaisen maatiaiskanan suojelua tehostetaan. Ngh-nytt 1: 7.

Kantanen, J. 2004. Mitä arvoa suomalaisella maatiaiskanalla? Pohjolan Geenivarat 2004: 8.

Kantanen, J. 2000. Suomalaisen maatiaiskanan turvaksi säilytysketju. Nytt fra NGH 1/2000: 6. Niemelä, T. 2000. Maatiaiskanakannat Suomessa. Suomen siipikarja 82: 26-27.

Niemelä, T. 1999. Maatiaiskanan paluu. Suomalaisen maatiaiskanan säilytysohjelma. Päättötyö. Uudenmaan Maaseutuopisto. Lokakuu 1999. 